\title{
KINESIO TAPING AND EXERCISE THERAPY FOR PHYSICAL THERAPY OF HEADACHE, AGAINST DYSPLASTIC INSTABILITY OF CERVICAL SPINE IN CHILDREN
}

\author{
Gorsha O. V., Korolenko N. V.
}

\section{INTRODUCTION}

Headache (HA) is one of the most common symptoms in modern clinical medicine, as more than $70 \%$ of the population of developed countries suffer from intermittent or systematically $\mathrm{HA}^{1}$. As a rule, the secondary nature of HA determines the importance of revealing a leading etiological factor, which the way and efficiency of treatment depend on ${ }^{2}$. One of the most common forms of the secondary cephalgia is "cervicogenic headache" (CHA). The pathophysiology of this type of headache requires further studying, although the assumption of a possibility of provoking headache pathology by the cervical spine (CS) has been discussed since 1925. The term CHA combines different mechanism types of headache associated with diseases and pathological condition of the cervical spine and other structures of the neck. The vertebral arteries (VA) locate at the narrow bone canal, created in the openings in the transverse processes of the cervical vertebrae, so even a relatively minor problem in the cervical spine affects their hemodynamics ${ }^{3}$.

Among children and adolescents, according to disaggregated data, more than $40 \%$ suffer from headache ${ }^{4}$. But despite a great number of researches,

\footnotetext{
${ }^{1}$ Кондратьев А.В., Шульмин А.В., Шнайдер Н.А., Ломакин А.И. Головная боль как медико-социальная проблема (обзор литературы). Неврология, нейропсихиатрия, психосоматика. 2017. № 9(2). С. 83-88. URL: https://doi.org/10.14412/ 2074-2711-2017-2-83-88 (дата звернення: 24.02.2020).

${ }^{2}$ Канукова 3.В., Цогоев А.С. Оптимизация восстановительного лечения детей с цервикогенной головной болью. Фундаментальные исследования. 2012. № 2/2. C. 303-307. URL: https://www.fundamental-research.ru/ru/article/view?id=29499 (дата звернення: 20.02.2020).

3 Калашников В.И. Транскраниальная допплерография у пациентов с головной болью напряжения и цервикогенной головной болью. Международный медицинский журнал. 2016. Т. 22, № 2. C. 100-104. URL: http://dspace.nbuv.gov.ua/bitstream/handle/ 123456789/114023/20-Kalashnykov.pdf?sequence=1 (дата звернення: 24.02.2020).

${ }^{4}$ Морозова Е.А., Морозов Д.В. Головная боль у детей: современные аспекты диагностики и лечения. Практическая медицина. 2013. № 1(66). C. 113-116. URL: https://cyberleninka.ru/article/n/golovnaya-bol-u-detey-sovremennye-aspekty-diagnostikii-lecheniya/viewer (дата звернення: 22.02.2020).
} 
the age aspect of cephalgia remain the least clarified. The cervicogenic cephalgic syndrome in children, in particular, may be one of the leading manifestations of dysplastic instability of cervical spine ${ }^{5}$. As under conditions that cause irritation of the vertebral arteries or irritation of the sensitive nerve roots, sympathetic nerves, the following reflex muscular tension of the neck and occipital region occurs, which can be a substrate of pain. Deterioration of quality of life of patients with CHA can be compared with that of migraine and the tension headache $e^{6,7}$.

Analysis of publications of the majority of researchers as for the problem of vertebrogenic pain syndromes demonstrated that combined drug-free and drug treatment is advisable ${ }^{8,9}$. But the main point is that the symptomatic approach to drug analgesia of HA is often incapable of solving this problem of cervicogenic nature. The drug-free methods are mainly based on a combination of three blocks: biomechanical correction of the spine, acupuncture and physiotherapy, kinesiotherapy. However, instability of cervical spine, children's age under 12 , and conducting therapy against a background of the pain syndrome dramatically limit the options for affection on CHA of junior school children.

Recently, not only in sports medicine, but also for the physical therapy of various pathologies in children and adults, the method of kinesio taping (KTP) is used, which contributes to the modeling the muscular-fascial segment, which occurs due to a certain tension and special gluing of tapes $^{10,11}$. An undoubted advantage of this method is the preservation of the

5 Кравченко А.И. Цефалгический синдром у детей при диспластической нестабильности шейного отдела позвоночника. Травма. 2013. Т. 14, № 5. С. 96-99. URL: http://nbuv.gov.ua/UJRN/Travma_2013_14_5_22 (дата звернення: 21.02.2020).

${ }^{6}$ Бобошко И.Е., Жданова Л.А., Новиков А.Е. Особенности реабилитационной помощи подросткам с головной болью напряжения, обусловленные их психосоматической конституцией. Российский педиатрический журнал. 2015. № 4. C. 14-19. URL: https://cyberleninka.ru/article/n/osobennosti-reabilitatsionnoy-pomoschipodrostkam-s-golovnoy-bolyu-napryazheniya-obuslovlennye-ih-psihosomaticheskoykonstitutsiey/viewer (дата звернення: 20.02.2020).

${ }^{7}$ Кондратьев А.В., Шульмин А.В., Шнайдер Н.А., Ломакин А.И. Вказана праця. C. $83-88$.

${ }^{8}$ Канукова 3.В., Цогоев А.С. Вказана праця. С. 303-307.

${ }^{9}$ Морозова Е.А., Морозов Д.В. Вказана праця. С. 113-116.

10 Горша О.В., Короленко Н.В. Спосіб лікування цервікогенного головного болю: пат. 112871 Україна: МПК (2016.01), А61F 13/02, А61F 5/00. № 201608661; заявл. 08.08.16; опубл. 26.12.16, Бюл. № 24. 2 с.

11 Короленко Н.В., Горша О.В. Клініко-функціональні аспекти відновного лікування дітей молодшого шкільного віку з цервікогенним головним болем на тлі нестабільності в шийному відділі хребта. Здобутки клінічної та експериментальної медицини. 2018. № 3. С. 69-74. URL: https://doi.org/10.11603/1811-2471.2018. v0.i3.9383 (дата звернення: 23.02.2020). 
active lifestyle of patients with some therapeutic immobilization and passive stimulation of certain segments of the spine or extremities.

So, the study of pathogenetic aspects of CHA therapy in children is conditioned by the prevalence, complexity and multifactoriality of etiopathogenetic mechanisms, restriction of the use of many medicines in the pediatric group and uncertainty of algorithms and methodological approaches to physical treatment methods of such pathology.

So, studying the clinical features, hemodynamics of vertebral basilar basin (VBB) vessels, emotional state, vegetative status of junior school children with CHA against a background of dysplastic instability of SP and results of effect of KTP and exercise therapy (ET) in these children with the aim of improving the efficiency of their physical therapy and rehabilitation is an important medical and social problem, which has determined the prerequisites for conducting this study.

The study was clinical, open, prospective, controlled. Methods of descriptive statistics and the statistical hypotheses testing were used to characterize and analyze the results of the study. The organization of the methodology met regulations of the Consensus on Biomedical Ethics and was conducted in accordance with the principles of evidence-based medicine.

\section{Clinical and functional characteristics of the examined cohort}

The first phase of the study consisted in studying clinical features of the condition of VBB vessels hemodynamics, psychoemotional state according to psychophysiological exam (tolerance to stress, attention, dynamic efficiency of the nervous system) and vegetative status in the children of junior school age with headache against a background of CS dysplastic instability.

96 junior school age children with headache against a background of CS instability (which formed the main group) were examined. In this group $52(54.17 \%)$ were girls, $44(45.83 \%)$ - were boys, the age median was $8(7.0 ; 10.0)$ years old, the disease duration median $-9(6.0 ; 12.0)$ months. Comparison with healthy children was performed to determine the initial health characteristics of pediatric patients with cervicogenic headache. For this purpose, the control group was formed, which included 30 healthy children. Among the children in the control group, girls were 17 (56.67\%) and boys - 13 (4 3.33\%), the median age $9(8.0 ; 9.0)$ years old.

The medical status of all children was studied using clinical and X-ray methods, transcranial Doppler ultrasound, psychophysiological tests and analysis of heart rate variability according to cardiointervalography (CIG). The results of the study of the medical status of pediatric patients (the main group) and its comparison with healthy children (the control 
group) revealed the following clinical and pathogenetic features of headache against CS dysplastic instability.

The first point. The pediatric patients had the intensity of headache according to visual analog scale (VAS) - $2.0(2.0 ; 3.0)$. The intensity of pain by VAS corresponded to 2.0 and 3.0 points in $75.0 \%$ of pediatric patients. Besides of headache, these children in $71.87 \%(69 / 96)$ of cases suffered from other complaints, such as: meteosensitivity (35.42\% (34/96)), rapid fatigability $(63.54 \%(61 / 96))$ and several complaints at the time (35.42\% (34/96)). The obtained data as for asthenoneurotic manifestations experimental values found good agreement with the literature data ${ }^{12,13}$. The authors show that with CS dysplastic instability, rapid fatigability is observed in $72.18 \%$ of patients.

Among the objective data, signs of undifferentiated dysplasia of connective tissue were more frequently reported: scoliotic posture or scoliosis, tension and tenderness of the cervical and occipital muscles (often asymmetrically), increased lumbar lordosis with recurvation in the joints $\chi^{2}=75.92, p=0.0000$ as compared to the control, the presence of more than 3 signs (41.67\% (40/96)), and with X-ray examination - the instability of cervical spine in three or more segments in 69/96 (71.88\%) and instability of cervical spine in two segments - in 23/96 (23.96\%) cases. Other authors note the presence of scoliotic posture or scoliosis in 38-84\%, signs of hypermobility of joints - up to $37 \%$ of children with the signs of connective tissue dysplasia ${ }^{14,15}$.

The second point. According to Doppler ultrasound, the children with headache against the background of CS instability have significant hemodynamic disturbance in the head and neck vessels system. Increase in blood flow velocity in both vertebral arteries (VA), particularly in intracranial (IC) segments is 1.4-1.6 times as compared with the control, a significant asymmetry of blood flow (IC $13.66(6.98 ; 18.32) \%$, EC 17.44 $(9.30 ; 25.32) \%)$ and a significant right-sided blood flow prevalence (intracranially in $69.8 \%$ of cases, $\chi^{2}=12.88 \mathrm{p}=0.0015$ ) was revealed. These changes are usually an adaptation mechanism and indicate the development of collateral circulation, which is the result of a possible compression or bending of vessels with CS instability. Reduced values of resistance index (IR) for the IC segments of both VA in the main group indicated a violation

${ }^{12}$ Веселова Т.В. Недиференційована дисплазія сполучної тканини - проблема та шляхи вирішення. 2017. № 3(54). С. 26-32. URL: https://d-l.com.ua/uploads/files/2017/ 3(54)/DL173_26-32_397229d443b50f8ed07f965493f426a0.pdf (дата звернення: 22.02.2020).

${ }^{13}$ Кравченко А.И. Вказана праця. С. 96-99.

${ }^{14}$ Веселова Т.В. Вказана праця. С. 26-32.

${ }^{15}$ Кравченко А.И. Вказана праця. С. 96-99. 
of the elastic properties of the vessels. The results of the rotating sample (RS) were adverse, since after its conduction, the blood flow rate in both VA decreased significantly (by 26.63-29.64\%) in almost all the children (95.8-97.9\%). This indicated a decrease in reserves and impaired blood flow in VA associated with the negative extravasal influence of the surrounding structures. Violations of venous blood flow were established as well (values of straight sinus and ocular veins are several fold enlarged - 1.5-2.4 times and, in all the cases, $\mathrm{p}=0.0000$ as compared to the control), which is an evidence of the difficulty and impairment of the venous blood flow.

According to the data of other researchers, violations of hemodynamics in the cervical spine and the brain take place of different extent of severity take place in all patients with CS dysplastic instability. In particular, the asymmetry of the blood flow in the vertebral arteries - in $80 \%$, the presence of congestive circulatory disorders - in $62 \%$ of examined children, disturbance of blood flow in the vertebral arteries - more than 15-20\%, often asymmetrical, when turning the head sideways the corresponding vertebral artery compression increases ${ }^{16}$.

The third point. Psychophysiological examination revealed significant disturbances of psycho-emotional state of children with headache against a background of CS dysplastic instability.

The tension level was assessed by the Luscher test (LT). In the main group, the deviation from the autogenic norm was 20.0 (18.00; 24.00) points, which indicated the predominance of non-productive neuropsychic tension when as compared with the control $(16.0(12.00 ; 20.00))$ points; $p=0.0000)$. The vegetative coefficient of LT in pediatric patients $(1.60(0.90 ; 2.00)$ points) also prevailed over the control values $(1.20$ (1.00; 1.50$)$ points; $\mathrm{p}=0.0078$ ). This testified to the reduction of pediatric patients approach to active activity.

Using the Schulte Table, the children's attention status was assessed. The duration of this test in children of the main group $(468.0(356.5 ; 545.5) \mathrm{sec})$ was significantly higher than in the control group $(223.0(194.0 ; 284.0) \mathrm{sec})-$ 2.1 times $(p=0.0000)$. This also concerns performance, which in the main group was $93.6(71.30 ; 109.10) \mathrm{sec})$ and exceeded the values in the control group $(45.9(39.00 ; 58.00) \mathrm{sec})$ - twice $(\mathrm{p}=0.0000)$. According to the "Scout" test, the volume of attention of children was estimated, which in the main group was significantly lower $(5.0(3.00 ; 6.00)$ units $)$ than in the control group (8.0 (7.00; 9.00) units) $(\mathrm{p}=0.0000)$. The redirecting child's attention function was studied using the Red and Black test: the number of errors (23.0 (17.00; $28.50) \%$ ) in the main group was 1.8 times greater than in the control group $(12.5(8.00 ; 18.00) \%) ; \mathrm{p}=0.0000)$.

\footnotetext{
${ }^{16}$ Калашников В.И. Вказана праця. С. 100-104.
} 
Psychomotor properties of the nervous system were established by the tap test: the dynamic performance of pediatric patients was statistically significantly lower $(456.5(444.0 ; 473.0)$ units $)$ than of the healthy children (488.5 $(482.0 ; 496.0))$ units, $\mathrm{p}=0.0000)$.

So, the pediatric patients with CHA against a background of CS instability are characterized by significant disturbances of psycho-emotional state by the psychophysiological examination, which were manifested as predominance of nonproductive neuropsychic tension and decreased performance, increased attentional resource allocation, errors in redirecting attention and disturbed volume of attention and neuromotor reaction.

The obtained data found good agreement with the literature data, which reveals that circulatory disorders in the VBB associated with cervicovertebral dysfunction was accompanied by dysregulation of subconscious mental functions, tension syndrome, mental exhaustion, and decreased performance. There is a break down of mainly subcortical effects on the mental state of the examined, in contrast to the cortical ones, which more specifically reflects the lack of the vertebral-basilar blood supply in contrast to the carotid one ${ }^{17,18}$.

The fourth point. The children with headache against a background of CS dysplastic instability were characterized by significant disorders of vegetative regulation according to $\mathrm{CIG}$, which was manifested by the management of cardiac rhythm with significant tension of regulatory systems, inadequate reactivity of the vegetative nervous system (VNS) to the external influences with impaired balance of its both parts functioning and significant advantage of parasympathetic effects on the heart rhythm. These children are revealed increasing of RR by $8.45 \%$, SDNN -2.4 times, RMSSD -4.1 times and pNN50 -2.3 times as compared with the healthy children (in all the cases $\mathrm{p}=0.0000$ ). The most patients were observed the vagotonic type of initial vegetative tone $\left(78.13 \%(75 / 96) \chi^{2}=61.16\right.$, $\mathrm{p}=0.0000$ as compared with the control) and the hypersympathicotonic type of vegetative reactivity (VR) $(84.38 \%(81 / 96)) \chi^{2}=85.99, p=0.0000$ as compared with the control).

Our finding experimental values found good agreement with the literature data, in which at evaluation of vegetative reactivity in children with different cephalalgia against a background prevalence of vagotonia hypersympathicotonic vegetative reactivity (VR) (31-51\%) was most

${ }^{17}$ Бобошко И.Е., Жданова Л.А., Новиков А.Е. Вказана праця. С. 14-19.

18 Пилина Г.С., Жуйкова П.В., Зямилова А.И. Головная боль у школьников: особенности соматического и эмоционально-когнитивного состояния. VI Балтийский конгресс по детской неврологии: сб. тезисов. Санкт-Петербург : Человек и его здоровье, 2016. С. 265-266. URL: https://congress-ph.ru/common/htdocs/ upload/fm/ d-nevro/16/tezis.pdf (дата звернення: 20.02.2020). 
commonly diagnosed. Others authors show that at studying vegetative homeostasis with the use of CIG and analysis of vegetative status in the children with headache, the vagotonic type of vegetative dystonia occurred in $43.2 \%$, the mixed one - in $45.9 \%$.

So, our findings confirm and complement existing perceptions of the health status of the children with headache against a background of CS dysplastic instability.

\section{Results of physical therapy of the children with cervicogenic headache}

The next task of the research was studying the effects of single and combined use of KTP and TE on clinical manifestation, the state of hemodynamics of vessels of the vertebrobasilar basin, psychophysiological state and vegetative status of the examined children immediately and at the remote period (in 1 and 6 months after the treatment).

In order to solve this problem, three subgroups of children were formed from the main group: the children of the 1st subgroup (36 persons) were applied KTP, children of the 2nd subgroup (30 persons) were applied ET, children of the 3rd subgroup (30 persons) were applied KTP and ET in combination. The initial values of all indicators of the study of each subgroup were compared with each other and it was found no difference between them, that is, the initial states of children of the three subgroups were comparable.

KTP was singlely applied for 36 children (1st subgroup) with headache against a background of CS dysplastic instability. The patients underwent the neck and collar muscle taping once a week. The tapes were on the skin for 5 days, followed by a 2-day break. Four such procedures were performed during a month ${ }^{19}$.

Analyzing the results achieved in the children of the 1st subgroup it was found that the use KTP led to a significant improvement in the clinical condition of the pediatric patients immediately after the treatment $(72.22 \%$ (26/36) did not report headache), but in 6 months the headache returned to $58.8 \%(16 / 30)$ of patients. The pain intensity median according to VAS immediately after therapy and in a 1 month was 1.0 point, but in 6 months 2.0 points). Although it should be noted that before the treatment according to VAS headache of 3 points gradation was recorded in $41.7 \%$ of children and in 6 months the percentage was $3.3 \%$ ( $p=0.0000$ as compared with the data before the therapy). There was no significant effect on the

19 Горша О.В., Короленко Н.В. Спосіб лікування цервікогенного головного болю: пат. 112871 Україна: МПК (2016.01), A61F 13/02, A61F 5/00. № 201608661; заявл. 08.08.16; опубл. 26.12.16, Бюл. № 24. 2 с. 
morphofunctional state of CS, but in 6 months after the treatment, the number of children with instability in three or more segments decreased from 72.2 to $46.7 \%$ of cases.

KTP improved blood flow in intracranial (IC) segments of both VA $(p=0.0000)$, normalized blood flow in extracranial (EC) segments of VA for the whole observation period (in 6 months the indicators also corresponded to the control values (correspondently $-\mathrm{p}=0.818$ ) $=0.662$ ), for a long time (during 6 months) improved the elastic properties of both VA in both IC and EC segments (reduced to treatment resistance index (IR) values of both VA in EC segments after use of KTP statistically significant $(\mathrm{p}<0.05)$ increased and began to correspond to the control values), according to the rotating sample for a short-term (up to 1 month) improved the impaired response of both VA (statistically significant for the right VA) on extravasal effects of surrounding structures, improved immediately after therapy and in 1 month venous outflow from the vessels of the head and neck, which is worsened further, but remained better than before the treatment (venous outflow parameters in terms of straight sinus and eye veins differed significantly $(p<0.05)$ concerning all indicators before the treatment).

The use of KTP reduced the increased level of anxiety in pediatric patients by the Luscher test (deviation from the autogenic norm decreased $(\mathrm{p}=0.00003)$, and persisted throughout the observation period, as well as in a statistically significant decrease of the vegetative factor immediately after the treatment and in 1 month after the treatment ( $\mathrm{p}<0.05)$, improved all investigated parameters of attention and dynamic performance (neuromotor response) of the children immediately after the treatment, which in the late period (in 6 months) deteriorated. After the effect the dynamic performance growth $(\mathrm{p}=0.0000)$ was observed, in 1 month this indicator did not improved $(480.50(470.0,486.0)$ units), but in 6 months deteriorated and was compliant with initial $(\mathrm{p}>0.05)$.

The effect of KTP on the vegetative regulation of heart rhythm in pediatric patients was manifested in improvement of all statistical and spectral indicators of CIG. The restoration of sympathetic influences and reduction of significant prevailing of parasympathetic influences on the rhythm of heart of the 1st subgroup children were noted. Such changes of vegetative parameters contributed to a significant increase in the frequency of eitonia in these children $(66.75 \%(24 / 36), \mathrm{p}<0.001$ as compared to initial frequency, but in 6 months the frequency of eitonia decreased to $33.3 \%$ $(10 / 30)$ but significantly $(p<0.001)$ exceeded the initial data $-16.67 \%$ (6/36), however, KTP did not affect the nature of vegetative reactivity, which remained predominantly hypersympathicotonic $(\mathrm{p}>0.05)$ during the whole observation period. 
The obtained results of KTP use with headache against a background of CS dysplastic instability in children one could not compare with the literature data in the absence of the similar studies.

So, our findings confirm the clinical and functional efficacy of treating children with headache against CS dysplastic instability by using KTP, but show a decrease in the most of achieved positive effects at the long-term follow-up (in 6 months). We received this data for the first time ${ }^{20,21}$.

ET aimed at forming a "muscular corset" of the spine and improvement of posture was singlely applied in 30 pediatric patients of the 2 nd subgroup. The course was 15 lessons in a day (during a month) ${ }^{22}$.

The use of ET course improved the clinical status of these patients immediately after the treatment, which resulted in a reduction in the incidence of headache complaints immediately after the treatment up to $36.7 \%(11 / 30)$ and the achieved effect was quite stable and even developed over time: in 1 month, the proportion of such children decreased to $33.33(10 / 30)$, but in 6 months it increased again to $52.9 \%(9 / 17))$. The median headache intensity according to VAS at all study points after the course was 1.0. point. It was not set a significant effect of ET on morphological functional state of CS except for decrease of number of children with instability at three or more segments from $70.0 \%(21 / 30)$ to $52.9 \%(9 / 17)$ cases $(\mathrm{p}<0.05)$.

The course of ET improved the blood flow in IC segments of both VA, asymmetry of IC blood flow decreased for a short time $(\mathrm{p}=0.0000)$ and did not differ from the control $(\mathrm{p}=0.1932)$, but then progressively increased again in 1 and 6 months); EC blood flow asymmetry was significantly ( $p<0.05$ at all points of observation) decreased for the whole study period (2.4 times) and did not differ from the values of the control group and also remained up to the 6th month of observation; for a long period normalized the elastic properties of both VA in both IC and EC departments, which began to correspond to the control values $(p>0.05)$; improved venous outflow from the vessels of the head and neck (for a long period on the straight sinus: $p=0.00000-p=0.00100$ according to indicators before the treatment at all points of observation). However, according to the rotating sample ET did not significantly affect the impaired response of both VA to the extravasal effects of the surrounding structures $(p>0.05)$.

${ }^{20}$ Горша О. В., Короленко Н. В. Спосіб лікування цервікогенного головного болю: пат. 112871 Україна: МПК (2016.01), A61F 13/02, A61F 5/00. № 201608661; заявл. 08.08.16; опубл. 26.12.16, Бюл. № 24. 2 с.

${ }^{21}$ Короленко Н.В., Горша О.В. Вказана праця. № 3. С. 69-74.

22 Виленская Т.Е. Физическое воспитание детей младшего школьного возраста: пособие. Ростов н/Д. : Феникс, 2006. 256 с. 
After application of ET elevated level of anxiety of these children didnot decrease and remained at this level before the treatment $(p>0.05)$. Other psychophysiologic indicators of the children of the 2 nd subgroup improved. However, only achieved effects of the allocation of attention reduced $(\mathrm{p}=0.0359)$ and continued to decline in 6 months) and rediracting attention (statistically significant reducing of errors $(p=0.0066)$ ), steady improved throughout the study and parameters of volume attention - short-term and deteriorated in 6 months. The use of the ET course led to improvement of the neuromotor response of children by the tap test, which resulted in an increase of dynamic performance immediately after the treatment $(p=0.0018)$ and in maintaining a similar value until the 6th month after the treatment.

The effect of ET on vegetative balance in pediatric patients was manifested as improvement of all statistical and spectral indicators of CIG, initial vegetative tone, and vegetative reactivity (VR), which was steady throughout the study. After the course, the parasympathetic effects on the heart rhythm of the children decreased and remained at the level throughout the study. The use of ET led to a significant increase of eitonia in all periods of study of children after the treatment: from $13.3 \%(4 / 30)$ to $63.3 \%(19 / 30)$ ( $\mathrm{p}<0.001)$, then in 1 month - up to $70.0 \%(21 / 30)$ ( $\mathrm{p}<0.001$ as compared with the initial frequency). In 6 months after the treatment, the eitonia frequency decreased to $52.9 \%(9 / 17)$ ( $\mathrm{p}<0.01$ as compared to the initial frequency). The similar dynamics was observed for VR in these children: it improved immediately after the treatment $(p=0.0237)$ and remained steady throughout the whole observation period.

Other authors also note improvement during the use of ET in patients with the cervicocranial spine pathology. In particular, a 3-5 times decrease in headache rate was noted, a tendency for normalization of indicators and coefficient of asymmetry of the vessels of the head and neck was established (normalization of vertebral basilar blood flow in 61\%, improvement of vertebral basilar blood flow in $15 \%$ ), and retention of the obtained effect from treatment up to 6 months $\mathrm{s}^{23,24}$.

The efficacy of combined use of KTP and ET was conducted in 30 children of the 3 rd subgroup. The use of this complex significantly improved the clinical condition of these children immediately after the

${ }^{23}$ Канукова 3.В., Цогоев А.С. Вказана праця. С. 303-307.

24 Усикова Т.Я., Кравченко А.И., Богданова Л.В., Валюшко Т.В. Опыт применения лечебной физкультуры в лечении диспластической нестабильности шейного отдела позвоночника у детей.. 2011. № 6(33). С. 60-63. URL: https://cyberleninka.ru/article/n/opyt-primeneniya-lechebnoy-fizkultury-v-lechenii-

displasticheskoy-nestabilnosti-sheynogo-otdela-pozvonochnika-u-detey/viewer (дата звернення: 24.02.2020). 
treatment $(86.67 \%$ (26/30) did not complain of HA), and the effect achieved was sufficiently steady - in 6 months the pain did not recur in most children $(69.2 \%(18 / 26))$. After the course of treatment, the headache intensity median according to VAS was 1.0 point in the majority of these children, whereas before the treatment $73.3 \%$ (22/30) evaluated the gradation of their pain from 2 to 4 points. According to X-ray data, the number of children with instability in three or more segments was reduced in 6 months to $26.9 \%$ of cases.

In the majority of patients of the 3rd subgroups after the course the blood flow in IC segments of both VA $(p=0.0000 ; p=0.0000)$ improved, its asymmetry reduced $(\mathrm{p}=0.0001$ - as compared with initial and control data $\mathrm{p}=0.83602)$ and the blood flow in the EC segments of both VA normalized $(\mathrm{p}=0.0004$ and $\mathrm{p}=0.0002)$ over the whole study period. A long term improvement of elastic properties of VA in both IC (according to IR $\mathrm{p}=0.0000$ in both cases) and EC (according to IR $\mathrm{p}=0.0031$ and $=0.0005$ ) of their segments was observed, reaction of both VAs on the negative extravasal effects of surrounding structures (by rotating sample). The indicators of the head and neck vessels outflow improved (both by the straight sinus $\mathrm{p}=0.0000$ and ocular veins $(\mathrm{p}=0.0000$ and $\mathrm{p}=0.0000)$.

Under the complex influence of KTP and ET, the increased level of anxiety decreased and reached the control values: deviation from the autogenous norm decreased $(\mathrm{p}=0.0000)$, the vegetative factor also decreased $(\mathrm{p}=0.0068)$. All investigated indicators of attention improved (duration of attention allocation $(\mathrm{p}=0.0000)$, attention redirecting improved which was manifested in reduction of errors $(p=0.0001)$, volume of attention $(p=0.0000))$ and dynamic performance $(p=0.0000)$. The achieved effects of redirecting attention and dynamic performance of children were steady throughout the study, and other psychophysiological indicators were more short-term (more than 1 month).

The effect of the combined use of KTP and ET on the vegetative balance in children of the 3rd subgroup manifested itself as improvement of all statistical (RR, SDNN, RMSSD, pNN50), and spectral indices (VLF, LF, HF) of cardiointervalogramm immediately after the treatment. The use of the complex led to a significant increase in eitonia - up to $76.7-61.5 \%$ at different points of the study, which significantly prevailed its availability before the treatment $(13.3 \%(4 / 30) \mathrm{p}=0.00263-\mathrm{p}=0.00000)$ and $\mathrm{a}$ significant improvement in vegetative reactivity (VR): the proportion of adverse hypersympathicotonic reaction decreased significantly to $30.0-65.4 \%$, and the number of sympathicotonic reaction increased to $30.8-66.7 \%$ (before the treatment $10.0 \%(3 / 30)$ ). These data indicate a significant improvement in vegetative regulation in these children, the achieved effect was steady throughout the whole study period. 
So, our findings confirm the effectiveness of physical therapy for headache against CS instability in children, through the use of KTP and ET. These data are unrivalled in literature and were obtained for the first time.

Discussing the obtained findings we should underline that both in single and complex use of KTP and ET in children with headache against a background of CS dysplastic instability a unidirectional favorable tendency of the most indicators of the study is achieved. However, a single use of ET did not change the initially higher level of anxiety of pediatric patients and impaired response of both vertebral arteries to extravasal influences of surrounding structures (according to the rotating sample $-\mathrm{p}>0.05$ ), and KTP did not affect the disturbed vegetative reactivity $\mathrm{p}>0.05$ ). Besides, the obtained results indicate the inability of the investigated methods of physical therapy to significantly influence the morphological changes in the cervical spine according to X-ray data (except for reducing the number of children with instability in 3 or more segments).

For the purpose of the comparative analysis, we additionally conducted a study of the achieved shifts of the study indicators in the examined children by the results of therapy, which is given in Table. 1 . This table reveals that the best clinical and functional effect immediately after the treatment and in 1 month came with combined use of KTP and ET, which in the first case was $24.12(-1.83 ; 24.24)$ in the second case $-23.91(1.07 ; 27.27) \%$ of favorable shift of values in comparison with the initial values. With single use of KTP and ET clinical functional and effects immediately after the course of treatment (correspondingly $17.15 \quad(-1.57 ; 19.88 \%$ and $17.60(-1.21 ; 17.85) \%)$ and in 1 month after the treatment (correspondingly $19.21(0.67 ; 19.67) \%$ and $18.58(-2.42,19.18) \%)$ were comparable among themselves and worse in comparison with the combined use of KTP and ET. In 6 months after the treatment, the achieved clinical and functional effects of the studied methods became comparable (see Table 1).

Discussing the achieved clinical and functional states of pediatric patients after the physical therapy and the effects according to the dynamics of indicators, we underline that the methods studied allow us to improve the health of children with headache against a background of CS instability. However, the combined use of KTP and ET led to the best and the most long-term clinical and functional effect. A little worse, but in many ways comparable, direct clinical and functional results come after the single use of KTP. This method leads to a good clinical effect, which manifests itself in significantly reduced headache, which does not occur with single use of ET. However, achieved with a singled use of KTP clinical and functional effects are more short-term, especially as compared to the combined use of KTP and ET. 
步

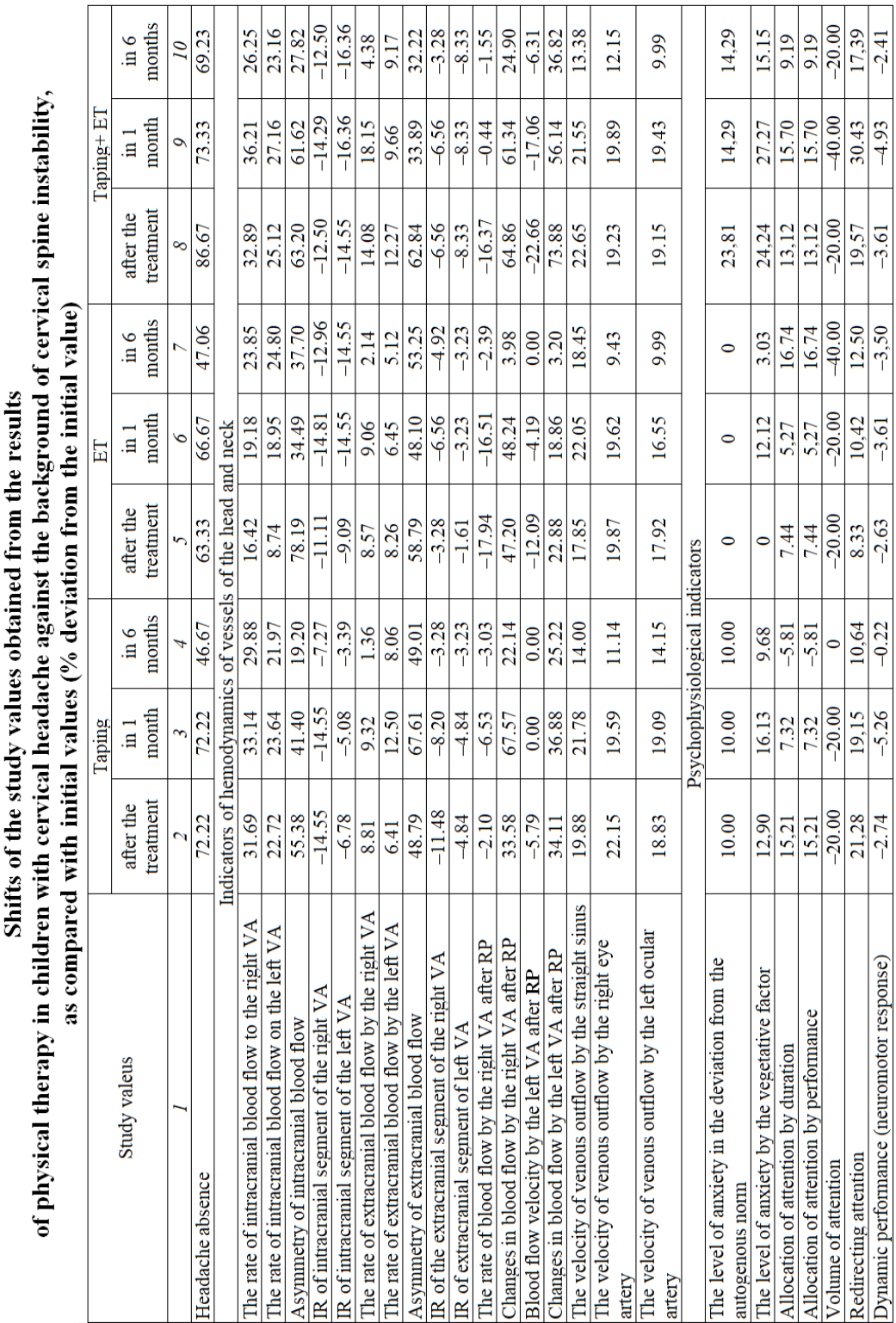




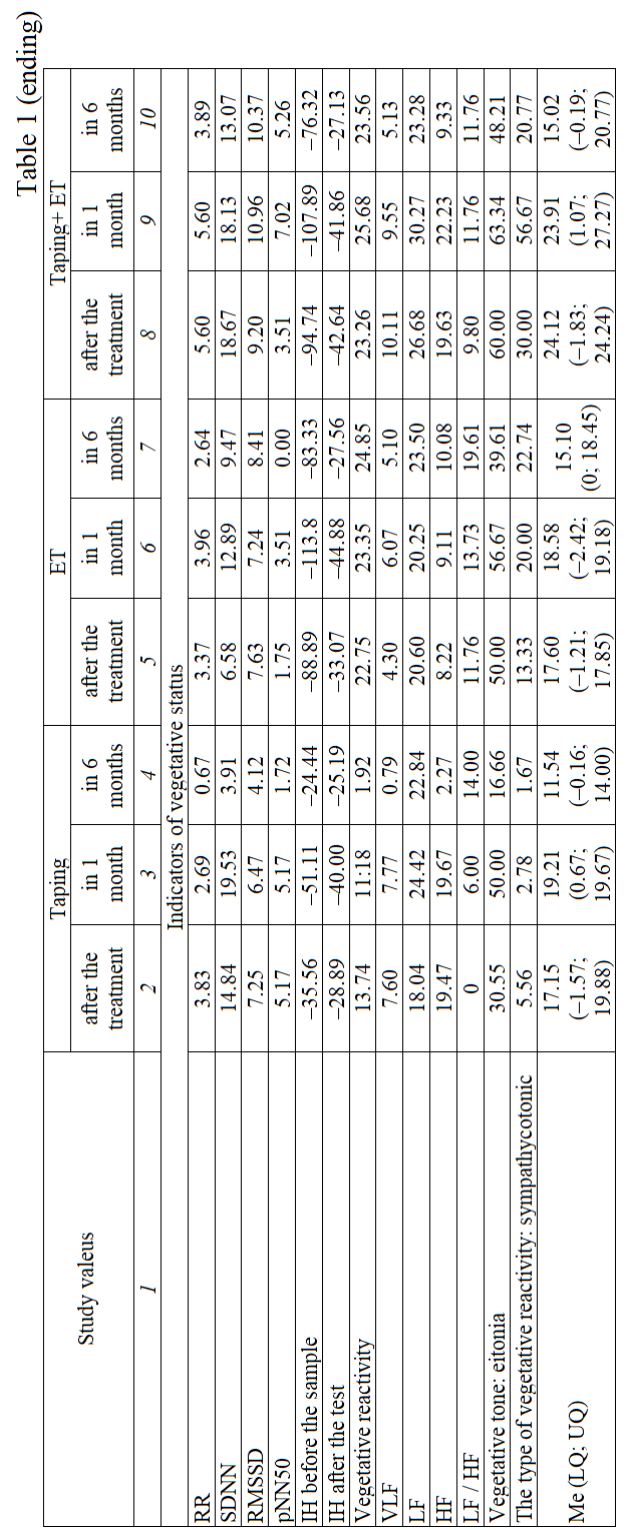


It should also be emphasized that a singled use of KTP has the smallest effect on the vegetative balance of pediatric patients and only for a short time optimizes the neuromotor response and response to the negative extravasal effects of VA. The worst direct clinical and functional results were characterized by a single ET use. This especially concerns the pain syndrome (the presence and intensity of HA), the level of anxiety, the reaction of VA to extravasal effects and the level of blood flow in the intracranial departments of both VA (a slight improvement over other methods of treatment). However, this method allows to achieve more longterm results of treatment, which is not peculiar to a single use of KTP.

So, in order to achieve better and long-term clinical and functional outcomes the method of choice is combination of KTP and ET. With the absence of an ability to perform ET and to achieve rapid immediate symptomatic clinical result (reduction or elimination of headache), one can recommend KTP. When using the investigated methods of medical rehabilitation, it is not possible to retain the achieved clinical and functional results of treatment for a long time (6 months), however, they still remain better than before the treatment. The regression of positive results after six months in some pediatric patients confirms the need of longer courses or their reoccurrence no later than in 6 months.

\section{CONCLUSIONS}

1. Junior school age children with headache against a background of CS instability suffer from other clinical changes (meteosensitivity, fast fatigue, scoliosis, tension and tenderness of neck and occipital muscles (often asymmetric), increased lumbar lordosis with joint recurvation); significant hemodynamic changes in the head and neck vessels; disturbance of psychoemotional state in the form of nonproductive nervous-mental tension, deterioration of attention and dynamic performance; violation of vegetative status.

2. Each of the research method leads to favorable dynamics of most parameters of examination and improves clinical condition (reducing the frequency and intensity of headache), vertebral basilar basin vessels hemodynamics (blood flow, elastic properties, reaction to the negative extravasal effects, venous outflow) psychophysiologic state (neuropsychological tension, attention, dynamic performance) and vegetative status of children with headache against a background of instability of cervical spine. A single use of exercise therapy did not change initially elevated level of anxiety of pediatric patients and disturbed reaction of vertebral arteries to extravasal effects, and kinesio taping had no effect on infringement of vegetative reactivity of pediatric patients. 
3. The analysis of achieved shifts of indicators of the study showed that the best clinical and functional effect comes with the combined use of kinesio taping and exercise therapy. Comparison of the effectiveness and duration of the results of the single application of the methods showed that exercise therapy provides a longer-term positive effect, but kinesio taping faster and better optimizes the clinical and functional state of pediatric patients immediately after the treatment (primarily it concerns the effect on the pain syndrome). Achieved in 6 months after the treatment clinical and functional effects of single and combined use of the methods are comparable and are better than before the physical therapy.

\section{SUMMARY}

To examine the effect of a separate and combined use of Kinesio Taping (KTP) and treatment exercises (TE) on the clinical and functional status of children with HA syndrome.

126 children of 6-11 years were examined, 96 of them had complaints of HA for 6 to 24 months. With the exclusion of other pathology and verification of the cervical spine instability, the cervicogenic nature of the headache was established. It was found that each of the studied methods improves the clinical condition (reduction of rate and intensity of headache: $72.2 \%$ (KTP), $63.3 \%$ (TE) and $86.7 \%$ (complex) of children did not have HA) after the treatment course, optimizes hemodynamics of vessels of the vertebral basilar basin, psychoemotional status of vegetative reactivity. The best and the longest clinical-functional effect was achieved with a combined usage of KTP and TE, persisted for more than 1 month and decreased after 6 months (although remained better than before treatment $(p<0.05)$ ).

The complex usage of KTP and TE reduces the manifestation of pain, optimizes clinical and functional indicators of the nervous system, improves the psychoemotional state, improving the quality of life of children with HA. The obtained results confirm the prospect of the use of these ERM methods for the treatment of cervicogenic headache and prove a necessity for further research of their medical and prophylactic efficacy.

\section{REFERENCES}

1. Бобошко И.Е., Жданова Л.А., Новиков А.Е. Особенности реабилитационной помощи подросткам с головной болью напряжения, обусловленные их психосоматической конституцией. Российский педиатрический журнал. 2015. № 4. C. 14-19. URL: https://cyberleninka.ru/ article/n/osobennosti-reabilitatsionnoy-pomoschi-podrostkam-s-golovnoybolyu-napryazheniya-obuslovlennye-ih-psihosomaticheskoykonstitutsiey/viewer (дата звернення: 20.02.2020). 
2. Веселова Т.В. Недиференційована дисплазія сполучної тканини - проблема та шляхи вирішення. 2017. № 3(54). Дитячий лікар. C. 26-32. URL: https://d-1.com.ua/uploads/files/2017/3(54)/DL173_2632_397229d443b50f8ed07f965493f426a0.pdf (дата звернення: 22.02.2020).

3. Виленская Т.Е. Физическое воспитание детей младшего школьного возраста : пособие. Ростов н/Д. : Феникс, 2006. 256 с.

4. Горша О.В., Короленко Н.В. Спосіб лікування цервікогенного головного болю: пат. 112871 Україна: МПК (2016.01), А61F 13/02, A61F 5/00. № 201608661; заявл. 08.08.16; опубл. 26.12.16, Бюл. № 24.2 c.

5. Калашников В.И. Транскраниальная допплерография у пациентов с головной болью напряжения и цервикогенной головной болью. Международный медицинский журнал. 2016. Т. 22, № 2. C. 100-104. URL: http://dspace.nbuv.gov.ua/bitstream/handle/123456789/ 114023/20-Kalashnykov.pdf?sequence = 1 (дата звернення: 24.02.2020)

6. Канукова 3.В., Цогоев А.С. Оптимизация восстановительного лечения детей с цервикогенной головной болью. Фундаментальные исследования. 2012. № 2/2. С. 303-307. URL: https://www.fundamentalresearch.ru/ru/article/view?id = 29499 (дата звернення: 20.02.2020).

7. Кондратьев А.В., Шульмин А.В., Шнайдер Н.А., Ломакин А.И. Головная боль как медико-социальная проблема (обзор литературы). Неврология, нейропсихиатрия, психосоматика. 2017. № 9 (2). С. 83-88. URL: https://doi.org/10.14412/2074-2711-2017-2-83-88 (дата звернення: 24.02.2020).

8. Короленко Н.В., Горша О.В. Клініко-функціональні аспекти відновного лікування дітей молодшого шкільного віку з цервікогенним головним болем на тлі нестабільності в шийному відділі хребта. Здобутки клінічної та експериментальної медицини. 2018. № 3. C. 69-74. URL: https://doi.org/10.11603/1811-2471.2018.v0.i3.9383 (дата звернення: 23.02.2020).

9. Кравченко А.И. Цефалгический синдром у детей при диспластической нестабильности шейного отдела позвоночника. Травма. 2013. Т. 14, № 5. С. 96-99. URL: http://nbuv.gov.ua/UJRN/ Travma_2013_14_5_22 (дата звернення: 21.02.2020)

10. Морозова Е. А., Морозов Д. В. Головная боль у детей: современные аспекты диагностики и лечения. Практическая медицина. 2013. № 1 (66). C. 113-116. URL: https://cyberleninka.ru/article/n/ golovnaya-bol-u-detey-sovremennye-aspekty-diagnostiki-i-lecheniya/viewer (дата звернення: 22.02.2020).

11. Пилина Г.С., Жуйкова П.В., Зямилова А.И. Головная боль у школьников: особенности соматического и эмоционально-когнитивного состояния. VI Балтийский конгресс по детской неврологии: сб. тезисов. 
Санкт-Петербург : Человек и его здоровье, 2016. С. 265-266. URL: https://congress-ph.ru/common/htdocs/upload/fm/d-nevro/16/tezis.pdf (дата звернення: 20.02.2020).

12. Усикова Т.Я., Кравченко А.И., Богданова Л.В., Валюшко Т.В. Опыт применения лечебной физкультуры в лечении диспластической нестабильности шейного отдела позвоночника у детей. Здоровье ребенка. 2011. № 6(33). C. 60-63. URL: https://cyberleninka.ru/article/n/opytprimeneniya-lechebnoy-fizkultury-v-lechenii-displasticheskoy-nestabilnostisheynogo-otdela-pozvonochnika-u-detey/viewer (дата звернення: 24.02.2020).

\section{Information about authors:} Gorsha O. V., Doctor of Medical Sciences, Professor at the Clinical Department of Medical Rehabilitation State Enterprise Ukrainian "Scientific and Research Institute of Transport Medicine under the Ministry of Health of Ukraine" 92, Kanatnaya str., Odessa, 65039, Ukraine

Korolenko N. V., Candidate of Medical Sciences, Odessa Regional Charity Rehabilitation Fund of Disabled Children "Future" 51, Pushkinskaya str., Odessa, 65048, Ukraine 